\title{
Trans Fatty Acids and Cardiovascular Disease Risk
}

\author{
A.M. Liontos, T.D. Filippatos, M. Georgoula and M.S. Elisaf
}

Department of Internal Medicine, School of Medicine, University of loannina, Ioannina, Greece

\begin{abstract}
Trans fatty acids (TFA) are fatty acids that contain at least one double bond that is in the trans configuration. TFA are consumed mainly with industrial partially hydrogenated vegetable fats that are used in the production of margarines and "shortenings". The consumption of ruminant TFA provide another source of TFA in European countries. TFA consumption generally increases total cholesterol and decreases high density lipoprotein cholesterol and is associated with increased risk of cardiovascular disease. The results of some large-scale epidemiological studies suggest that the increased cardiovascular disease risk with the consumption of TFA is possibly greater than would be predicted from changes in plasma lipid levels alone. The experience from different countries shows that the elimination of TFA is a cost effective and feasible public health intervention. Based on the scientific evidence, the consumption of TFA should be further targeted aiming to further reduce of TFA in fast food products and the implementation of newer industrial methods that produce vegetable oils with lower (or even zero) amounts of TFA.
\end{abstract}

Keywords: Trans fatty acids, fatty acids, lipids, diet, cardiovascular disease, cholesterol, hydrogenated oil.

Trans fatty acids (TFA) are fatty acids that contain at least one double bond that is in the trans configuration [1]. In human diets, TFA may arise from three sources [2]. The main source in most countries originates from the industrial partial hydrogenation of foods, which is an industrial process that reduces the unsaturation of fatty acids. This process results in solid vegetable fats that are used in the production of margarines and "shortenings", which in turn are used for cooking. TFA from partially hydrogenated oils can be found in margarine and other spreads, coffee creamer, baked goods such as cakes, cookies and pies, frozen pizza, snack foods such as microwave popcorn, and refrigerator dough products such as biscuits and cinnamon rolls. Indeed, margarines may contain from 1-2\% (high-quality margarine) to $60 \%$ (low-quality margarine) TFA [3]. The second source is the biohydrogenation, which is observed in nature and mainly results from the enzymatic transformation of cisfatty acids into TFA by the bacterial flora of the rumen of animals (e.g. cows, sheep, goats). Ruminant TFA provide up to $10 \%$ of total fatty acids and consumed primarily with milk products (e.g. butter, cheese) and meats $[4,5]$. The third source, which represents a minor source, is originated by extreme thermal treatments of food, which is observed, among others, in domestic processes such as long-time baking at high temperatures, dry pan frying or barbecue [6].

Several meta-analyses of controlled dietary interventions that examined the relationship between TFA intake and lipid levels consistently report a dose-

*Address correspondence to this author at the Department of Internal Medicine, School of Medicine, University of Ioannina, 45110 loannina, Greece;

Tel: +302651007509; Fax: +302651007016; E-mail: egepi@cc.uoi.gr related impairment of lipid levels [7-11]. TFA are associated with an increase of total cholesterol (TC) and low-density lipoprotein cholesterol (LDL-C) levels, a decrease of high-density lipoprotein cholesterol (HDL-C) levels, and in some studies an elevation of serum triglycerides (TG) concentration [12-16]. It seems that the substitution of TFA for cis unsaturated fatty acids results in elevation of TC and LDL-C levels, whereas the substitution for saturated fatty acids results in a decrease of HDL-C levels and increase of TG concentration and the TC/HDL-C ratio $[12,17,18]$. In a meta-analysis of 60 selected trials, the isoenergetic replacement of trans $18: 1$ constituting $1 \%$ of energy with saturated fatty acids decreased TC/HDL-C ratio by 0.019 . The isoenergetic replacement with cis monounsaturated fatty acids decreased TC/HDL-C ratio by 0.048 and with cis polyunsaturated fatty acids by 0.054 [19]. When TFA constituting $1 \%$ of energy were isoenergetically replaced with a 1:1:1 mixture of carbohydrates, cis monounsaturated fatty acids, and cis polyunsaturated fatty acids, then the TC/HDL-C ratio decreased by 0.04. The detrimental effect of TFA is also demonstrated by the fact that the isoenergetic replacement of TFA constituting $1 \%$ of energy with carbohydrates has the same effect on TC/HDL-C ratio as with the isoenergetic replacement of saturated fatty acids constituting $7.3 \%$ of energy with carbohydrates [19]. The increase in TC/HDL-C ratio with the consumption of TFA is clinically important since it is associated with increased cardiovascular disease (CVD) risk [20].

These harmful effects of TFA on lipidemic parameters have been attributed to decreased rates of apolipoprotein B-100 catabolism, increased rates of 
apolipoprotein A-I catabolism, and increased activity of cholesteryl ester transfer protein. Evidence from animal studies indicate that TFA suppress hepatic LDL receptor activity [21]. In vitro studies also have implicated TFA with decreased lecithin:cholesterol acyltransferase activity $[9,22,23]$. Interestingly, prospective studies have shown that the actual incidence of CVD attributed to TFA intake is greater than that predicted by changes in serum lipids alone $[9$, 24-27]. Thus, effects of TFA on other additional risk factors have been proposed, such as the increase of lipoprotein (a) levels or the association with cardiac arrhythmias or sudden cardiac arrest [7, 9]. Additionally, TFA consumption has been associated with endothelial dysfunction and an increase of soluble inter-cellular adhesion molecule 1 , soluble vascular-cell adhesion molecule 1, E-selectin, tumor necrosis factor$\alpha$, interleukin- 6 and C-reactive protein [28].

It should be mentioned that in European countries TFA derived from milk and ruminant fat comprises a large proportion of total TFA consumption. Indeed, the ruminant TFA exceeds $50 \%$ of total TFA consumption in the Mediterranean countries [29]. There is a debate if the intake of TFA derived from ruminant fats has a similar association with CVD as with the intake of industrial hydrogenated fats [30-32]. However, in the Zutphen Elderly Study the intakes of both ruminant and industrially produced TFA predicted a higher risk of coronary artery disease [25]. Furthermore, a quantitative review of the literature concluded that TFA derived from any source increase the LDL-C/HDL-C ratio [33]. The consumption of ruminant TFA is low in most countries ( $<1 \%$ of energy), because ruminant fat contains low levels of TFA. Generally, the amounts of ruminant TFA that is actually consumed does not seem to provide a significant contribution to CVD risk compared with industrially-derived TFA [34]. In any case, the intake of ruminant TFA can be kept low by the consumption of skimmed dairy products and lean meat.

The experience from different countries shows that the elimination of TFA is a cost effective and feasible public health intervention. Recently, the United States Food and Drug Administration (FDA) made a preliminary determination that partially hydrogenated oils, the major dietary source of TFA in the processed food supply, are no longer Generally Recognized as Safe (GRAS) [35]. Before that announcement, the World Health Organization had recommended that TFA should be limited to less than $1 \%$ of daily caloric intake [36], and United States had mandated labeling of foods with more than $0.5 \mathrm{~g}$ of TFA content per serving [37]. In European Union, Denmark and Switzerland introduced laws strictly regulating the sale of many foods containing TFA, which limit TFA to $<2 \%$ of fats and oils destined for human consumption. Based on the scientific evidence, the consumption of TFA should be further targeted. The fast food industry should be encouraged to decrease the amount of TFA content in their products. Furthermore, newer industrial methods should be employed in order to produce vegetable oils with lower (or even zero) amounts of TFA.

\section{REFERENCES}

[1] Eckel RH, Borra S, Lichtenstein AH, Yin-Piazza SY Understanding the complexity of trans fatty acid reduction in the American diet: American Heart Association Trans Fat Conference 2006: report of the Trans Fat Conference Planning Group. Circulation 2007; 115: 2231-46. http://dx.doi.org/10.1161/CIRCULATIONAHA.106.181947

[2] Menaa F, Menaa A, Menaa B, Treton J. Trans-fatty acids, dangerous bonds for health? A background review paper of their use, consumption, health implications and regulation in France. Eur J Nutr 2013; 52: 1289-302. http://dx.doi.org/10.1007/s00394-012-0484-4

[3] Precht D, Molkentin J. Recent trends in the fatty acid composition of German sunflower margarines, shortenings and cooking fats with emphasis on individual C16:1, C18:1, C18:2, C18:3 and C20:1 trans isomers. Nahrung 2000; 44: 222-8.

http://dx.doi.org/10.1002/1521

3803(20000701)44:4<222::AID-FOOD222>3.0.CO;2-9

[4] Sommerfeld M. Trans unsaturated fatty acids in natural products and processed foods. Prog Lipid Res 1983; 22: 221-33.

http://dx.doi.org/10.1016/0163-7827(83)90010-3

[5] Precht D. Variation of trans fatty acids in milk fats. Z Ernahrungswiss 1995; 34: 27-9. http://dx.doi.org/10.1007/BF01612782

[6] Sebedio JL, Grandgirard A, Prevost J. Linoleic acid isomers in heat treated sunflower oils. J Am Oil Chem Soc 1988; 65: 362-6.

http://dx.doi.org/10.1007/BF02663077

[7] Mozaffarian D, Clarke R. Quantitative effects on cardiovascular risk factors and coronary heart disease risk of replacing partially hydrogenated vegetable oils with other fats and oils. Eur J Clin Nutr 2009; 63 Suppl 2: S22-33.

http://dx.doi.org/10.1038/sj.ejcn.1602976

[8] Clarke R, Frost C, Collins R, Appleby P, Peto R. Dietary lipids and blood cholesterol: quantitative meta-analysis of metabolic ward studies. BMJ 1997; 314: 112-7. http://dx.doi.org/10.1136/bmi.314.7074.112

[9] Mozaffarian D, Katan MB, Ascherio A, Stampfer MJ, Willett WC. Trans fatty acids and cardiovascular disease. N Engl J Med 2006; 354: 1601-13. http://dx.doi.org/10.1056/NEJMra054035

[10] Ascherio A, Katan MB, Zock PL, Stampfer MJ, Willett WC Trans fatty acids and coronary heart disease. $N$ Engl J Med 1999; 340: 1994-8.

http://dx.doi.org/10.1056/NEJM199906243402511

[11] Booker CS, Mann JI. Trans fatty acids and cardiovascular health: translation of the evidence base. Nutr Metab Cardiovasc Dis 2008; 18: 448-56.

http://dx.doi.org/10.1016/j.numecd.2008.02.005 
[12] Mensink RP, Katan MB. Effect of dietary trans fatty acids on high-density and low-density lipoprotein cholesterol levels in healthy subjects. N Engl J Med 1990; 323: 439-45. http://dx.doi.org/10.1056/NEJM199008163230703

[13] Clevidence BA, Judd JT, Schaefer EJ et al. Plasma lipoprotein (a) levels in men and women consuming diets enriched in saturated, cis-, or trans-monounsaturated fatty acids. Arterioscler Thromb Vasc Biol 1997; 17: 1657-61. http://dx.doi.org/10.1161/01.ATV.17.9.1657

[14] Lichtenstein AH, Ausman LM, Carrasco W, Jenner JL, Ordovas JM, Schaefer EJ. Hydrogenation impairs the hypolipidemic effect of corn oil in humans. Hydrogenation, trans fatty acids, and plasma lipids. Arterioscler Thromb 1993; 13: 154-61. http://dx.doi.org/10.1161/01.ATV.13.2.154

[15] Zock PL, Katan MB. Hydrogenation alternatives: effects of trans fatty acids and stearic acid versus linoleic acid on serum lipids and lipoproteins in humans. J Lipid Res 1992; 33: 399-410.

[16] Sundram K, Ismail A, Hayes KC, Jeyamalar R, Pathmanathan R. Trans (elaidic) fatty acids adversely affect the lipoprotein profile relative to specific saturated fatty acids in humans. J Nutr 1997; 127: 514S-20S.

[17] Judd JT, Clevidence BA, Muesing RA, Wittes J, Sunkin ME, Podczasy JJ. Dietary trans fatty acids: effects on plasma lipids and lipoproteins of healthy men and women. Am J Clin Nutr 1994; 59: 861-8.

[18] Lichtenstein AH, Ausman LM, Jalbert SM, Schaefer EJ. Effects of different forms of dietary hydrogenated fats on serum lipoprotein cholesterol levels. N Engl J Med 1999; 340: 1933-40. http://dx.doi.org/10.1056/NEJM199906243402501

[19] Mensink RP, Zock PL, Kester AD, Katan MB. Effects of dietary fatty acids and carbohydrates on the ratio of serum total to HDL cholesterol and on serum lipids and apolipoproteins: a meta-analysis of 60 controlled trials. Am J Clin Nutr 2003; 77: 1146-55.

[20] Tanaka F, Makita S, Onoda T et al. Predictive value of lipoprotein indices for residual risk of acute myocardial infarction and sudden death in men with low-density lipoprotein cholesterol levels $<120$ mg/dl. Am J Cardiol 2013; 112: 1063-8.

http://dx.doi.org/10.1016/j.amjcard.2013.05.049

[21] Hayashi $\mathrm{K}$, Hirata $\mathrm{Y}, \mathrm{Kurushima} \mathrm{H}$ et al. Effect of dietary hydrogenated corn oil (trans-octadecenoate rich oil) on plasma and hepatic cholesterol metabolism in the hamster. Atherosclerosis 1993; 99: 97-106. http://dx.doi.org/10.1016/0021-9150(93)90055-Y

[22] Mozaffarian D. Trans fatty acids - effects on systemic inflammation and endothelial function. Atheroscler Suppl 2006; 7: 29-32.

http://dx.doi.org/10.1016/j.atherosclerosissup.2006.04.007

[23] Mohammadifard N, Nazem M, Naderi GA et al. Effect of hydrogenated, liquid and ghee oils on serum lipids profile. ARYA Atheroscler 2010; 6: 16-22.

[24] Micha R, Mozaffarian D. Trans fatty acids: effects on cardiometabolic health and implications for policy. Prostaglandins Leukot Essent Fatty Acids 2008; 79: 147-52. http://dx.doi.org/10.1016/j.plefa.2008.09.008
Oomen CM, Ocke MC, Feskens EJ, van Erp-Baart MA, Kok FJ, Kromhout D. Association between trans fatty acid intake and 10-year risk of coronary heart disease in the Zutphen Elderly Study: a prospective population-based study. Lancet 2001; 357: 746-51. http://dx.doi.org/10.1016/S0140-6736(00)04166-0

[26] Kromhout D, Menotti A, Bloemberg B et al. Dietary saturated and trans fatty acids and cholesterol and 25-year mortality from coronary heart disease: the Seven Countries Study. Prev Med 1995; 24: 308-15. http://dx.doi.org/10.1006/pmed.1995.1049

[27] Hu FB, Stampfer MJ, Manson JE et al. Dietary fat intake and the risk of coronary heart disease in women. $\mathrm{N}$ Engl $\mathrm{J}$ Med 1997; 337: 1491-9. http://dx.doi.org/10.1056/NEJM199711203372102

[28] Bhardwaj S, Passi SJ, Misra A. Overview of trans fatty acids: biochemistry and health effects. Diabetes Metab Syndr 2011; 5: 161-4.

http://dx.doi.org/10.1016/j.dsx.2012.03.002

[29] Hulshof KF, van Erp-Baart MA, Anttolainen M et al. Intake of fatty acids in western Europe with emphasis on trans fatty acids: the TRANSFAIR Study. Eur J Clin Nutr 1999; 53: 14357.

\section{http://dx.doi.org/10.1038/sj.ejcn.1600692}

[30] Gebauer SK, Chardigny JM, Jakobsen MU et al. Effects of ruminant trans fatty acids on cardiovascular disease and cancer: a comprehensive review of epidemiological, clinical, and mechanistic studies. Adv Nutr 2011; 2: 332-54. http://dx.doi.org/10.3945/an.111.000521

[31] Willett W, Mozaffarian D. Ruminant or industrial sources of trans fatty acids: public health issue or food label skirmish? Am J Clin Nutr 2008; 87: 515-6.

[32] Baer DJ. What do we really know about the health effects of natural sources of trans fatty acids? Am J Clin Nutr 2012; 95: 267-8.

http://dx.doi.org/10.3945/ajcn.111.031096

[33] Brouwer IA, Wanders AJ, Katan MB. Effect of animal and industrial trans fatty acids on HDL and LDL cholesterol levels in humans--a quantitative review. PLoS One 2010; 5: e9434.

[34] Dhaka V, Gulia N, Ahlawat KS, Khatkar BS. Trans fatssources, health risks and alternative approach - A review. J Food Sci Technol 2011; 48: 534-41. http://dx.doi.org/10.1007/s13197-010-0225-8

[35] Food and Drug Administration. Questions and answers regarding Trans Fat. http://www.fda.gov/Food/PopularTopics/ ucm373922.htm. Accessed at 8-4-14.

[36] World Health Organization. Diet, nutrition and the prevention of chronic diseases: report of a joint WHO/FAO expert consultation. WHO Technical Report Series No. 916. Geneva. 2003:

[37] US Food and Drug Administration. Guidance for Industry: Trans Fatty Acids in Nutrition Labeling, Nutrient Content Claims, Health Claims; Small Entity Compliance Guide. http://www.fda.gov/food/guidanceregulation/guidancedocume ntsregulatoryinformation/labelingnutrition/ucm053479. htm. Accessed at 20-5-14. 